\title{
The Ineffectiveness and Inadequacies of International Instruments in Combatting and Ending the Transboundary Movement of Hazardous Wastes and Environmental Degradation in Africa
}

\author{
Avitus A. Agbor
}

School of Postgraduate Studies and Research, Faculty of Law, North-West University, South Africa aagbor@gmail.com

\begin{abstract}
Despite the fact that international instruments prohibit such activities, recent recurrent incidents involving the transboundary movement of hazardous wastes on the African continent highlight their inadequacies and ineffectiveness of international law in solving this problem. Despite some noticeable milestones achieved by the Bamako Convention, its shortcomings are conspicuous. In addition, the ban on transboundary movement of hazardous wastes is simply one dimension of the bigger problem faced by (many poor) African countries: poor management of the environment that ranges from water and air pollution, poor disposal of wastes, improper and inadequate treatment of domestically generated hazardous wastes, congestion, noise, and dumping. These international instruments deal with only a dimension of the problem faced by African states. It is argued that additional measures must be taken to complement these efforts. Such measures include the enactment of strong laws and policies, education of the masses and a virile civil society.
\end{abstract}

\section{Keywords}

environmental management - transboundary movement of hazardous wastes - civil society and environmental management - Basel and Bamako Conventions - toxic waste dumping in Africa 
In the past few decades, most Africa countries have been consigned to the status of a dumping site of hazardous materials, especially from developed industrialised countries. Despite the relevant international instruments that prohibit such acts, not so much has been done by the vast majority of African states to end this illicit activity. International law, especially international agreements, so far, has proved to be inadequate in combating and ending the transboundary movement of hazardous wastes. Evidence to corroborate this view lies in the numerous incidents involving the transboundary movement of hazardous wastes into Africa, despatched from developed industrialised countries. More specifically and applicable to Africa is the Bamako Convention the international instrument developed by African states recognising the challenges specific to the continent on this issue. Hazardous wastes continue to be moved from industrialised developed countries to poor African countries where economic realities and weak legal institutions inhibit the effective implementation of international law, norms and standards with regard to the environment. The proposed merged African Court of Justice and Human and Peoples' Rights will have jurisdiction over numerous crimes, amongst which is the transboundary movement of hazardous wastes. In addition, its imposition of criminal responsibility for the crimes over which it will have jurisdiction is not limited to individuals. These distinct features are unprecedented in international (criminal) law, and can therefore be perceived as colossal steps towards the complete eradication of transboundary movement of hazardous wastes. Our optimism, however, must be cautious for the simple reason that transboundary movement of hazardous wastes is simply a specific and lone dimension of the problem confronting the environment in many African countries: increased human movement into the cities and the resulting noise and congestion, an augmented generation of domestic refuse and the inability of the government to deal with it adequately, water and air pollution, are some of the dangers posed to the environment in major African cities. These other broader issues related to the environment signal the urgent necessity of African states to take a more holistic approach to solving these challenges.

This paper argues that, as evidenced by the cases that have occurred in the past decades, international instruments that deal with the issue of transboundary movement of hazardous wastes are in themselves insufficient and ineffective. Moreover, they are limited as they address only a specific issue that affects the environment. Rather, given the various kinds of activities that contribute to environmental degradation in Africa, a more comprehensive approach should be taken to uphold, promote and protect the environment. Reliance 
on international instruments will be irrational and illogical. Instead, African states must develop strong legal systems built on rule of law, with sound laws and policies enacted and implemented so as to address these challenges. In addition, environmental education must be taken into every corner of every African society in the hope that its dwellers understand and appreciate the relationship they have with their environment as well as recognise what role they must play to safeguard it. Thirdly, a virile civil society dominated by environmental non-governmental organisations (NGOs) is much needed in order to achieve environmental justice, monitor compliance with laws, and serve as the think tank to policies that affect the environment.

This paper examines first, the issue of transboundary movement of hazardous wastes, looking into the how, the why, and the what questions. Secondly, it assesses the relevant international instruments that deal with the issue of transboundary movement of hazardous wastes with specific focus on Africa. Thirdly, it looks into the complementary role played by effective and lucid environmental laws and policies, a culture of accountability and transparency as a cornerstone of good governance, environmental protection and sustainability, and lastly, how civil society can be priceless in the protection of the environment.

\section{Delineating the Issue of Transboundary Movement of Hazardous Wastes}

A few years ago, Abidjan, a major metropolitan city in the West African state of Côte d'Ivoire was the destination for the dumping of hazardous wastes comprising a blend of caustic soda, fuel, and hydrogen sulphide amounting to a weight of not less than five hundred tons was distributed to almost twelve sites around this city. ${ }^{1}$ Commonly referred to as the 'Côte d'Ivoire toxic waste

1 Even though there are some inaccuracies with regard to the exact quantity, in August 2006, over 500 tons of petrochemicals containing a mixture of petroleum distillates, hydrogen sulphide, mercaptans, phenolic compounds and sodium hydroxide were dumped around 15 sites in Abidjan. This dumping was done by a Dutch company, Trafigura. A few days later, several thousands of people started complaining of nosebleeds, nausea, skin and eye irritations, headaches, respiratory distress, intestinal bleeding and dehydration. New York Times reported how the foul smell of rotten eggs, garlic and petroleum hit the 14 affected cities of Côte d'Ivoire. It cost over one hundred lives. Over 80,00o sought medical treatment: see Barry Manson, 'Toxic Waste Dumping in Ivory Coast' (24 October 2006) < http://www.wsws .org/articles/2006/oct2006/ivor-o24.shtml> accessed 7 July 2014. This case bears plenty of similarity with the 1988 Koko, Nigeria, toxic waste dumping incident that occurred before 
dump, ${ }^{2}$ this triggered diverse response from governmental leaders, academics, environmentalists and health practitioners. It raised serious concerns on the efficacy in the management of hazardous wastes and the resulting impact of such hazardous wastes on the environment. Lives were lost, severe harm was caused to human health, and tens of thousands of people were injured. ${ }^{3}$ Legal and political responses to this environmental crisis led to civil actions against the wrongdoers: by October 2009, Trafigura had paid close to US\$ 200 million to the Ivorian government for clean-up costs. In addition, an offer of GBP 30 million was made to the injured victims. Despite these dimensions of legal closure to this environmentally wrongful act, it is highly probable that the inhabitants of this area would continue to suffer the effects of this crisis.

The Côte d'Ivoire toxic waste dump evokes some disturbing memories. Taking the guise of toxic terrorism, it revives the issue of, in the words of Laura A Pratt, 'toxic waste colonialism.4 Such transboundary movement of hazardous waste constitutes a flagrant violation of the core principles of international law. It must be highlighted, however, that such cross-border transportation of hazardous wastes, especially those from the developed to developing countries, as it happened in the Côte d'Ivoire case, is not unprecedented in international law. There have been cases of transboundary movement of hazardous wastes. In hope of protecting developing countries where there are less stringent environmental standards and the absence of techniques and technology to deal with such environmental nuisance, the international community tried to develop a corpus of international agreements that would govern the transboundary transportation of hazardous wastes. In 1989, the main international agreement on this issue, the Basel Convention on the Transboundary Movements of Hazardous Wastes and Their Disposal (hereafter referred to as

the adoption of the Bamako Convention. See also Adam Duckett, 'Trafigura Story Breaks' (The Chemical Engineer, 13 October 2009) <http://www.tcetoday.com/tcetoday/NewsDetail .aspx?nid=12188> accessed 7 July 2014.

2 Laura A Pratt, 'Decreasing Dirty Dumping? A Reevaluation of Toxic Waste Colonialism and the Global Management of Transboundary Hazardous Waste' (2011) 35 William \& Mary Environmental Law and Policy Review 581, 583. See also Amnesty International, 'Côte d'Ivoire Toxic Waste Dump Victims Reflect on "Small Victory"' (10 November 2009) $<$ http://www.amnesty.org/en/news-and-updates/news/cote-d'ivoire-toxic-waste-dump -victims-reflect-quotsmall-victoryquot-20og1110 $>$.

3 Manson (n 1).

4 Pratt uses this phraseology to be descriptive of the practice whereby 'underdeveloped states are used as inexpensive alternatives for the export or disposal of hazardous waste pollution by developed states'. See Pratt (n 2$) 5^{82}$. 
the Basel Convention), ${ }^{5}$ was adopted. The Basel Convention would ultimately become the foundational pillar for subsequent protocols. Almost thirty years since the Basel Convention addressed this issue, in all fairness and objectivity, one can postulate that transboundary transportation of hazardous wastes has not stopped. Rather, it has developed into an outlawed business activity with superb viability for profiteering. However, the Ivorian experience arouses some serious concerns: first, the effectiveness of international instruments as mechanisms to solve the problem, and secondly, that the current efforts at implementing the terms of these treaties and the policies of hazardous wastes management pose disproportionate risks when compared to the countries wherefrom they come.

These transboundary movements of hazardous wastes from developed countries to Africa (especially Sub-Saharan Africa) do pose a serious threat to the African people. Unfortunately, most of the potential victims of such illegal cross-border transportation of hazardous wastes are unable to appreciate the different dimensions of the ramifications posed to both their health and environment. The situation is further worsened by the fact that the ultimate destinations of these hazardous wastes, African states, are completely ill-equipped with the technology and know-how on how to handle the consequences that follow.

The repetitiveness of this grave and disturbing problem has triggered different kinds of responses by the international community: both at global and regional levels. Such responses have been marked by commitments and progressive efforts to put in place specific regulations aimed at monitoring the cross-border transportation of hazardous wastes. These efforts and commitments crystallised into two international instruments specifically dealing with the issue of transboundary movement of hazardous wastes: first, at the global level, the Basel Convention (discussed below). The Basel Convention represents a colossal breakthrough by the global community in reaching a consensus on regulating and monitoring the movement of hazardous wastes beyond national borders. It was followed by the United Nations Environment Program's adoption of the Cairo Guidelines and Principles for Environmentally Sound Management of Hazardous Wastes. ${ }^{6}$ Secondly, at regional level, a significant and important instrument on this issue is the Bamako Convention,

5 Basel Convention on the Transboundary Movements of Hazardous Wastes and Their Disposal, 1673 U.N.T.S. 126; 28 I LM 657 (1989).

6 Cairo Guidelines and Principles for the Environmentally Sound Management of Hazardous Wastes: Decision 14/30 of the Governing Council of UNEP of 17 June 1987. 
adopted by the then-OAU. The Bamako Convention is Africa's efforts to ban the acceptance of hazardous materials by all member states.

Despite these efforts and instruments, clandestine movements of hazardous wastes, usually from developed industrialised states to developing states, have been on the surge. The continuity of these unlawful and dangerous activities has called into question the effectiveness of these international instruments in dealing with this problem. Of greater worry is how these hazardous wastes are transported beyond national borders into, and within, Africa.

\subsection{Transboundary Movements of Hazardous Wastes: The History}

The uncontrolled and unregulated dumping of hazardous wastes in Africa is not new. Such illegal practices can be traced back to the early 1970 s when reports of clandestine deals that took place between some African countries and western companies (United States, United Kingdom, France, Germany, Italy, Switzerland and the former Soviet Union) began resurfacing. Rumours that there were sites of toxic wastes on African soil were soon validated and corroborated by evidence that included leaking barrels (see Nigeria Case) and aerial photographs of a constructed dumping site (see Benin Case).

Industrialisation, no doubt, has produced its own share of social costs. The increase in industrialisation in the past decades has been matched by increase in social costs. One of these is the high increase in the production of byproducts and wastes which, often, are toxic and hazardous to land, air and water as well as living creatures thereon if these wastes are not treated and disposed of appropriately. Even though there are difficulties in giving an accurate measurement of quantities of hazardous wastes produced worldwide, as of 1945, the worldwide generation of hazardous wastes was estimated to be around five million metric tons. By the year 2000, it had reached an estimated four hundred million metric tons. Seventy-five per cent of this comes from developed industrialised states. As the quantity of waste is not expected to reduce, it is estimated that by the year 2020, the total production of hazardous wastes in the developed world could have increased by sixty per cent to 194 million tons annually. ${ }^{7}$

7 See David Hunter, James Salzman and Durwood Zaelke, International Environmental Law and Policy (3rd edn, Foundation Press 2007) 947; David Naguib Pellow, Resisting Global Toxics: Transnational Movements for Environmental Justice (MIT Press Books 2007) 33. 

Wastes: The How Question

Incidents that have occurred on the African soil have resulted in some stunning and vexing revelations: poor African states have been designated as the dumping ground for hazardous wastes. Emanating from developed industrialised states, these hazardous wastes include chemical substances, raw sewage, incinerated ashes, sludge, contaminated oils, acids, radioactive materials, poisonous solvents that have been ejected by chemical, pharmaceutical and fertilizer producing plants. ${ }^{8}$ The Benin Case, ${ }^{9}$ the Shell Petroleum Development Company Case,${ }^{10}$ the Sao Tome Case,${ }^{11}$ the Somalia Case,${ }^{12}$ the Côte d'Ivoire Case ${ }^{13}$

8 Lisa Mastny and Hilary French, 'Crimes of (a) Global Nature: Forging Environmental Treaties is Difficult. Enforcing Them is Even Tougher' (World Watch, September-October 2002) < http://www.worldwatch.org/node/523> accessed 7 July 2014. Worthy of note is the fact that the new trend is the shipment of hazardous electronic wastes (or 'e-wastes' as commonly called): see Stephanie Condon, 'Congress Tackles E-Waste in the House and Nationally' (CNET, 11 February 2009, 4:45 PM PST) <http://news.cnet.com/8301-13578_3 -10162214-38.html> accessed 7 July 2014.

9 In the late 1980s, Benin, a poor West African country, experienced intense economic challenges: severe balance of payments deficit, inability to pay workers' salaries, and defaulted in its payment of its external debt. Given these dire crises, toxic wastes deals were brokered with the government of Benin. First, between 1984 and 1986, it is alleged that 'several tons' of radioactive waste were dumped by the then Soviet Union in Benin according to a senior Benin government official living in forced exile in Paris. It was alleged that the then President Kerekou was aware of the surreptitious dumping deal. In 1988, a bilateral deal was negotiated with the French government. The deal comprised the importation of radioactive and industrial waste in return for US\$1.6 million down payment and 30 years of economic assistance. The French were forced to cancel the deal because of massive media opposition in France. Still in 1988, the government of Benin signed another deal with an Anglo-American company, Sesco-Gibraltar, that called for the country to stockpile as much as 50 million tons of toxic wastes over a ten year period. See Benin Hazardous Waste available at $<$ wwwı.american.edu/ted/benin.htm $>$ accessed on 7 January 2015.

10 Innocent Anaba, 'Oil Spill: Shell to pay Ni5.4bn' (Vanguard Media Limited, 6 July 2010) http://www.vanguardngr.com/2010/o7/oil-spill-shell-to-pay-n15-4bn/> accessed on 7 January 2015 .

11 See Sao Tome Waste Case available at <http://wwwi.american.edu/ted/SAOTOME.HTM > accessed on 7 January 2015 .

12 See Somalia Waste Case available at <http://wwwı.american.edu/ted/SOMALIA.HTM> accessed on 7 January 2015 .

13 Manson (n 1). 
and the Nigeria Case,$^{14}$ to name a few, are some of the very recent incidents that have occurred on the African soil.

Most often, the transportation of hazardous wastes to Africa is done clandestinely. Hazardous wastes are bought and sold like any other commodity in the market. There are 'toxic commodity brokers' who operate in the shadows from a number of operating sites (some of which include Gibraltar, the Isle of Man, and Liechtenstein). Most often, the destinations of the ships are covert, and their contents are marked as harmless items such as fertilizers or building materials. It is a very simple and straightforward process that begins with the registration of a private company, then the purchase of wastes materials without any questions asked. The greatest and most daunting challenge is to find a dumping site. Renting a ship as well as hiring a crew are relatively easy tasks. Of all these, the easiest part is watching the money come in.

\subsection{Transboundary Movements of Hazardous Wastes to and in Africa: The Why Question}

The question to be asked is why is Africa designated as the ultimate destination for these hazardous wastes? Different reasons explain the repetitive nature of this illegal act. First, and obviously, some of the blame goes to economic pressure. African states involved in cross-border movement of hazardous wastes are driven by a desperate need to earn income as big as (and even bigger than) their GNPs. Rated as the predominant reason behind this, there is an economic drive from developing countries to earn income in the form of hard currency as an attempt to alleviate the economic hardships in which its people are entangled..$^{15}$

Furthermore, the greed that is exemplified by African business tycoons in their unquenchable desire to make enormous amounts of money in foreign currency in a relatively short span of time accounts for this. There have been reports of independent African business owners signing deals to import waste

14 See Nigeria Waste Case available at $<$ www1.american.edu/ted/nigeria.htm $>$ accessed on 7 January 2015 .

15 Mary Critharis, 'Third World Nations are Down in the Dumps: The Export of Hazardous Waste' (1990) 16 Brook. J. Int'l L. 311, 315. See also Jennifer R. Kitt Jennifer R. Kitt, Note, 'Waste Exports to the Developing World: A Global Response' (1995) 7 Geo. Int'l Envt'l L. Rev. P. 490, where she describes the proposed Guinea-Bissau hazardous wastes contract which promised an income equivalent to four times the country's GNP (twice its national debt). As Kitt opines, 'Developing countries may assess costs and risks differently that wealthy countries would because of their need to provide food, shelter, water and services to their citizens. Environmental risks may not seem as immediate as housing and disease prevention ...' (at 491). 
materials for just a portion of the cost of having these toxic wastes recycled or disposed of in the West.

Developed industrialised countries, wherefrom these hazardous wastes emanate, have very high regulatory standards (even though at times they are marred by some industrial and legal loopholes). ${ }^{16}$ Furthermore, the disposal of industrial wastes and by-products involves very high costs. ${ }^{17}$ The better and more affordable alternative is Africa where regulatory standards are low and enforcement is very weak, added to the low costs of recycling. Developed countries have continually targeted Africa as the destination for hazardous wastes under the pretext of re-use and recycling. Little wonder it has earned the moniker 'the dumping ground' as it is a very lucrative business that has enjoyed unprecedented growth. Hazardous wastes crossing national boundaries are shipped to Africa clandestinely and dumped on huge portions of unused land.

Industrial by-products contain numerous chemicals and substances. Most of these substances can neither be recycled nor disposed of easily. As a result, the disposal of hazardous wastes has become one of the biggest challenges faced by industrialised countries. This is exacerbated by the fact that more countries do fill up their landfills. In addition to this, the costs of disposing hazardous wastes are skyrocketing: in industrialised nations, the costs average approximately US $\$ 3000$ per ton. African states provide a better and affordable alternative to such high costs. In Africa, the sale of untreated waste can be as low as US\$ 5 per ton. ${ }^{18}$ When these costs are translated to the amount of expected profits, it leaves no room for doubt that Africa becomes the preferred destination for the dumping of hazardous wastes. ${ }^{19}$ The enormity of the profits explain why African leaders and business gurus would always consider shortterm profiteering over public safety even though the cost of cleaning up the

$16 \quad \operatorname{Kitt}(\mathrm{n} 15)_{15} 48-88$.

17 See generally Ron Chepesiuk, 'How the West is Dumping on the Third World: The Toxic Trade Nightmare' (Orlando Sentinel Trib., 8 July 1990) <http://articles.orlandosentinel .com/2990-07-08/news/9007060921_1_1toxic-waste-radioactive-wastes-tons-of-waste> accessed 7 July 2014.

18 Hunter (n 7) 948.

19 See generally Pellow ( $\left.n_{7}\right)$. 
effects of this toxic dumping and the unpalatable ramifications it has on the health of the surrounding and its people do outweigh such short-term benefits.

Having discussed the history, trends and why these wastes are moved to Africa, it is important to examine the international regulatory framework prohibiting this activity.

\section{$4 \quad$ The International Regulatory Framework}

The issue of transboundary movement of hazardous wastes is not an only an African problem. It is a global problem. Furthermore, from global levels, different responses have been made by the various regions across the world, developing specific instruments that recognise their peculiarities and stipulate ways and mechanisms to meet them. At global level, the instrument that deals with the issue of transboundary movement of hazardous waste is the Basel Convention. In addition to the Basel Convention, and limited to the African continent, is the Bamako Convention, developed and adopted specifically to deal with the issue of transboundary movement of hazardous wastes. In an effort to respond to the numerous incidents that have taken place on the African soil, transboundary movement of hazardous wastes will be an international crime over which the proposed merged African Court will have jurisdiction. This section contains a synoptic discussion of the international regulatory framework, beginning with the Basel Convention.

\subsection{The Basel Convention}

Growth in science and technology has led to a massive scale of industrialisation. In consequence, there has been a corresponding increase in activities that have a negative impact on the environment. Such negative impact has identifiable and measurable dimensions on human life, marine life, and ecosystem. In consequence, a cornucopia of municipal legislation and policies as well as international instruments are in place to ensure that the environment is protected. Of critical and particular importance is the transportation of hazardous wastes across national borders (jurisprudentially referred to as transboundary movement of hazardous wastes). More specifically, the transportation of such hazardous wastes from developed to developing countries, depicting some sort of toxic colonialism.

This North-South transportation of hazardous wastes highlights a few things: first, the lack of effective laws, policies and technology to deal with the problem of hazardous wastes in developing countries. Developed countries, wherefrom these hazardous wastes emanate, are equipped with the necessary 
waste management tools to deal with such issues. In addition, very strict environmental legislations and policies coupled to an increasing public awareness on the damaging effects of poor wastes management have resulted in a growing scarcity of disposal facilities added to the increasing disposal costs. ${ }^{20}$

Secondly, developing countries, specifically Africa, have been the destination for hazardous wastes partly because African countries provide cheaper waste disposal options. ${ }^{21}$ African states are beset with low environmental protection standards, the conspicuous lack of public opposition as a result of lack of awareness and information, and the absence of stringent laws, policies and regulations in place. The situation is compounded by the weak and corrupt leadership as state officials in African countries compromise international regulations and municipal laws in acceptance of gifts even though such hazardous wastes are harmful to both the peoples and environment. Little wonder why the African continent in particular, and developing countries in general, have become the ultimate destination and cesspit for all forms of hazardous wastes (without the exclusion of e-wastes). ${ }^{22}$ These hazardous wastes are generated in, and by, developed, industrialised countries. ${ }^{23}$

Such dangerous and illegal transportation of hazardous wastes beyond national borders spurred the international community to develop mechanisms to deal with it. The development of an international legal regime to adequately deal with this problem was rigorously pursued over the past decades. It reached its apex in the late 1970s to early 1980s, culminating in the adoption of the Basel

20 See generally the following: Kummer K, International Management of Hazardous Wastes: The Basel Convention and Related Legal Rules (Clarendon Press 1995); Eze CN, ‘The Bamako Convention on the Ban of the Import into Africa and the Control of the Transboundary Movement and Management of Hazardous Wastes Within Africa: A Milestone in Environmental Protection?' (2007) 15 AJICL 208.

21 Research conducted in the 1980 s revealed that the average disposal cost for one ton of hazardous waste in Africa was between US \$2.50 and US \$50, with equivalent costs in the industrialized nations ranging from US $\$ 100$ and US \$200o. See Kwiatkowska B and Soons AH (eds), Transboundary Movement and Disposal of Hazardous Wastes in International Law: Basic Documents (Martinus Nijhoff/Graham \& Trotman 1993).

22 'E-wastes' do comprise remains of computers, mobile phones and a vast variety of other electronic and electrical appliances which the original users no longer want.

23 See for example, in 1988, when the Government of Guinea-Bissau, one of Africa's poorest nations, agreed to accept over 15 million tons of toxic wastes for US $\$ 600$ million: an amount four times its GNP. The Minister of Trade and Tourism retorted, 'We need money': 'Africa: The Industrial World's Dumping Ground?', African Business (July 1988) 10-11. 
Convention. ${ }^{24}$ The adoption of the Basel Convention was a monumental stride made by the international community in combating this ailment.

The Basel Convention is a global instrument. Its roots can be traced to the United Nations Convention on Human Environment where it was recommended that a UN environmental organisation should be established. As a result, in 1972, the United Nations General Assembly created the United Nations Environmental Programme (UNEP). In order to identify areas that require increased cooperation both at global and regional levels in environmental law, a group of legal experts and government representatives were mandated by UNEP's Governing Council. Amongst others, they pointed out the need for increased international regulation of the transport, handling and disposal of hazardous and toxic wastes. As a follow up, in 1982, UNEP's Governing Council mandated another group of experts to develop guidelines and principles on environmentally sound management and transportation of hazardous wastes. In 1987, UNEP's Governing Council approved these guidelines.

During this period, increased awareness on the dangerous impacts of hazardous wastes on both the environment and human health took place. In consequence, there was a proliferation of national legislations relating to disposal of hazardous wastes in the domestic legal regime of developed countries. ${ }^{25}$ With increase in science, technology, industrialisation, awareness and legislations regulating the use of the environment, disposal costs of hazardous wastes increased as the availability of disposal sites decreased. These factors would militate to trigger a surge in the export of hazardous wastes to developing and Eastern European countries where adequately stringent rules on hazardous wastes disposal were, and are still very lacking.

The activities spurred public outcries. In reaction, numerous working groups continued to meet to develop a holistic global instrument on the control of transboundary movements of hazardous wastes. The outcome of this was a Conference of the Plenipotentiaries on the Global Convention on the Control of Transboundary Movements of Hazardous Wastes convened in

24 This instrument was opened for signature on 22 March 1989. It entered into force on 5 May 1992 in accordance with Article 25(1) of the Convention. As of 10 January 2015, there are 181 States party to the Convention, added to 53 signatories. Information available at <http://www.basel.int/Countries/StatusofRatifications/PartiesSignatories> accessed on 10 January 2015.

25 Webster-Main, mentions two examples from the United States: first, The Resource Conservation and Recovery Act (RCRA) 1976; and secondly, the Comprehensive Environmental Response, Compensation and Liability Act (CERCLA), 1994. See generally Webster-Main A, 'Keeping Africa out of the Global Backyard: A Comparative Study of the Basel and Bamako Conventions' (2002) 26/1 Environs, ELPJ 63, 68. 
Basel, Switzerland, in March 1989 that resulted in the adoption of the Basel Convention. ${ }^{26}$

\subsection{The Bamako Convention}

The Basel Convention epitomises a global attempt to bring together the numerous divergent views of states which were in favour of a complete ban on trade in hazardous wastes as the only way to ensure that developed countries dealt with their wastes rather than use developing countries with weaker economies as the dumping ground. However, some countries were of the opinion that a total ban was not in the interest of their economic or environmental development. ${ }^{27}$ As of February 2014, 180 states and the European Union are parties to the Basel Convention, making it one of the most universally ratified and recognised multi-lateral environmental agreements. ${ }^{28}$

However, there was a regional shift triggered by the African continent as it felt that their peculiar circumstances were neither considered nor addressed by the Convention. The second instrument is the Bamako Convention. The Basel Convention permits parties to enter into bilateral, regional or multilateral agreements regarding the transboundary movements of hazardous wastes. ${ }^{29}$ However, such agreements (whether bilateral, regional or multilateral) must not derogate from the environmentally sound management of wastes prescribed by the Convention. ${ }^{30}$ This would result in the adoption of the Bamako Convention on the Ban of the Import into Africa and the Control of the Transboundary Movement and Management of Hazardous Wastes within Africa 1991. ${ }^{31}$ This was done under the auspices of the defunct OAU. ${ }^{32}$

Even before the Basel Convention was adopted, African states grouped under the OAU were of the opinion that the Basel Convention would not afford to African countries adequate protection from transboundary movement of

26 The Basel Convention entered into force on 5 May, 1992, in accordance with Article 25(1) of the Convention.

27 These countries included non-European industrialized countries, a few developing countries such as India and Pakistan. See Webster-Main (n 25) 70.

28 Haiti and the United States have not ratified the Basel Convention. However, they are signatories to it.

29 Basel Convention, Article 11.

$30 \quad$ Ibid.

31 It was opened for signature on 30 January 1991, and went into force on 22 April 1998. As of 10 January 2015, 24 African states had ratified the Convention, and 30 states had signed it. Information available at <http://en.wikipedia.org/wiki/Bamako_Convention> accessed on 10 January 2015.

32 Now defunct, it was replaced by the African Union. 
hazardous wastes. In fact, Africa had advocated for a complete prohibition of transboundary movement of hazardous wastes rather than the development and adoption of mere regulation or control. This was partly attributable to the fact that developed countries wherefrom these hazardous wastes emanate do have the regulatory and technological mechanisms in place to regulate and control such scandalous, dangerous and hazardous activities.

African states, grouped under the defunct OAU, believed strongly that for reasons such as political instability, economic difficulties, corruption and the prevalent lack of the relevant and adequate knowledge in Africa, members could easily be lured with money to legitimise and condone what would otherwise be environmentally unacceptable. In fact, Africa could become the dumping ground for toxic wastes. As a result, the OAU Council of Ministers, in 1988, passed a resolution (the Cairo Guidelines) stating that the import of hazardous wastes into Africa was a crime against Africa and its people and that states should introduce import bans and adhere to the provisions of the Cairo Guidelines. ${ }^{33}$ Furthermore, the Resolution requested African countries to reach an agreement on a common African position to deal with the inadequacies of the draft Convention and to ensure that their unity was not disrupted until the draft Convention is adopted. ${ }^{34}$ Consequently, from 1989 to 1990 , the reaction from OAU member states was an unequivocal refusal to sign the Basel Convention. ${ }^{35}$ In July 1989 , a resolution was passed with a mandate to draft a reciprocal commitment of African states among themselves. The specific aim was to secure the implementation and effective prohibition of the importation of hazardous wastes into Africa. ${ }^{36}$ After this, a working group was set up to draft a Convention to provide for, and effectively ban, the importation of hazardous wastes into Africa and to effectively manage hazardous wastes generated within Africa. ${ }^{37}$ On 30 January 1991, at the Pan-African Conference on

33 Resolution 1153, OAU Council of Ministers Resolution on Dumping of Nuclear and Industrial Waste in Africa, 23 May 1988 (CM/Res. 1153 (XLVIII) reported in 28 ILM 567 (1989)).

34 The first African state to ratify the Basel Convention was Nigeria on 31 March 1991.

35 Webster-Main (n 25) 72.

36 Resolution on Control of Transboundary Movements of Hazardous Wastes and Their Disposal in Africa, OAU Council of Ministers Res. CM/Res. 1225(L) (22 July 1989), reprinted in UNGaor, 44th Session at 62-63, U.N. Doc. A/44/603 (1989). See also Wylie DJ, 'The Bamako Convention as a Solution to the Problem of Hazardous Wastes Exports to Less Developed Countries' (1992) 17(2) CJEL (footnote 5, 431).

Ibid. 
Environment and Sustainable Development in Africa, the Bamako Convention was adopted..$^{38}$

These international instruments aside, cross-border transportation of hazardous wastes into Africa has not stopped. While the 2006 Abidjan toxic disaster, the 2006 SPDC dumping of radioactive wastes in Nigeria, and the recent arrest of a vessel loaded with toxic waste are too recent to be ignored, they do evoke serious questions as to why the clandestine trade has not stopped. In other words, the effectiveness and adequacy of the legal framework regulating the transboundary movement of hazardous wastes has to be interrogated.

The Criminalisation of Trafficking of Hazardous Wastes by the Statute of the Merged African Court

As discussed above, the Basel and Bamako Conventions, two instruments at global and regional levels aimed at prohibiting transboundary movements of hazardous wastes, are inadequate and ineffective. More specifically, regarding the African continent and its economic realities, these two instruments do not provide a watertight regulatory framework required to combat illicit activities of such nature. The absence of such an effective regulatory framework at national levels is compounded by dire economic circumstances experienced by African states. The parlousness of these economic circumstances transcends personal lines as states agents have been complicit in the negotiation and completion of transactions involving transboundary movements of hazardous wastes. The case of Guinea-Bissau is an eloquent example of how state authorities could compromise international instruments and the rights and welfare of its people because of economic factors. In addition, it reveals a very simple fact: the illicit transportation of hazardous wastes in Africa is not limited to individuals who pursue such an option as a bailout to their economic woes. States are also involved.

Even though the adoption and ratification of the Basel and Bamako Conventions indicate global and regional consensus on combatting this illegal activity, these two instruments have proved to be ineffective and inadequate in curbing the problem of transboundary movement of hazardous wastes. States parties to these instruments are to develop and adopt national policies that give effect to the contents of these instruments. In addition, awareness on the

38 Bamako Convention on the ban on the Import into Africa and the Control of Transboundary Movement and Management of Hazardous Wastes within Africa, 30 ILM $773(1551)$. 
perilous consequences of these hazardous materials to both human life and health and the environment must be made. Civil society and state authorities should complement each other in the realisation of these hopes. Unless every stakeholder is involved, it would be completely difficult to abolish the importation into, and transportation within, Africa, of hazardous wastes.

In addition to the international legal framework that bans the transboundary movement of hazardous wastes, the African Union is currently taking steps to complement the Bamako Convention by criminalising transboundary movements of hazardous wastes. The 2012 African Union's Draft Protocol on the African Court of Justice and Human and Peoples' Rights that would establish the African Court of Justice and Human and Peoples' Rights does not only criminalise the illicit trafficking of hazardous wastes, but raises it to an international crime on the African continent over which the said Court would have jurisdiction.

\subsection{The Definition of Illegal Trafficking of Hazardous Wastes}

The Draft Protocol enlists the crimes over which the Court would have jurisdiction. ${ }^{39}$ Amongst others is the crime of trafficking of hazardous wastes, which is defined in Article $28 \mathrm{~L}$ of the Draft Protocol as follows:

Article 28L: Trafficking in Hazardous Wastes

1. For the purposes of this Statute, any import or failure to re-import, trans-boundary movement, or export of hazardous wastes proscribed by

39 Article 28A: International Criminal Jurisdiction of the Court.

1. Subject to the right of appeal, the International Criminal Law Section of the Court shall have power to try persons for the crimes provided hereunder:

1. Genocide

2. Crimes Against Humanity

3. War Crimes

4. The Crime of Unconstitutional Change of Government

5. Piracy

6. Terrorism

7. Mercenarism

8. Corruption

9. Money Laundering

10. Trafficking in Persons

11. Trafficking in Drugs

12. Trafficking in Hazardous Wastes

13. Illicit Exploitation of Natural Resources

14. The Crime of Aggression 
the Bamako Convention on the Ban of the Import into Africa and the Control of Trans-boundary Movement and Management of Hazardous Wastes within Africa, adopted in Bamako, Mali, in January 1991 shall constitute the offence of trafficking in hazardous waste.

2. The following substances shall be "hazardous wastes" for the purpose of this statute:

a. Wastes that belong to any category contained in Annex I of the Bamako Convention;

b. Wastes that are not covered under paragraph (a) above but are defined as, or are considered to be, hazardous wastes by the domestic legislation of the State of export, import or transit;

c. Wastes which possess any of the characteristics contained in Annex II of the Bamako Convention;

d. Hazardous substances which have been banned, cancelled or refused registration by government regulatory action, or voluntarily withdrawn from registration in the State of manufacture, for human health or environmental reasons.

3. Wastes which, as a result of being radioactive, are subject to any international control systems, including international instruments, applying specifically to radioactive materials are included in the scope of this Convention.

4. Wastes which derive from the normal operations of a ship, the discharge of which is covered by another international instrument, shall not fall within the scope of this Convention.

5. For the purposes of this Article, "failure to re-import" shall have the same meaning assigned to it in the Bamako Convention.

6. The export of hazardous waste into a Member State for the purpose of rendering it safe shall not constitute an offence under this Article.

In defining what constitutes hazardous wastes, the Draft Protocol makes references to the Bamako Convention. However, in some instances, the Draft Protocol articulates a definition if not within the purview of the Bamako Convention. An example of this is Article $28 \mathrm{~L}(2)$ (b) wherein the definition of hazardous wastes is expanded to cover some situations not stipulated in the Bamako Convention. Also, Article 28L(3) addresses a particular category of wastes - radioactive - that are not covered in Annexes I and II of the Bamako Convention. Article 28L(4) excludes wastes that emanate from the normal operations of a ship. In addition, the Draft Protocol expands the contents of hazardous wastes to include hazardous substances 'which have been banned, cancelled or refused registration by government regulatory action, 
or voluntarily withdrawn from registration in the State of manufacture, for human health or environmental reasons. ${ }^{40}$

\subsection{Standing before the Court}

In addition to stipulating what crimes the Court will have jurisdiction over, the Draft Protocol also articulates what entities would be eligible to submit cases to the Court. In addition to the Assembly, the Peace and Security Council and the Office of the Prosecutor, African individuals or African Non-Governmental Organisations will be able to submit cases to the Court. In the case of submissions by African Non-Governmental Organisations, such Organisations must have an Observer Status with the African Union, its organs or institutions. Submissions by African individuals and Non-Governmental Organisations can only be made against a State that has made a Declaration accepting the competence of the Court to receive cases or applications submitted directly to it. Cases or applications involving a State Party which has not made a Declaration in accordance with Article 9(3) of the Protocol shall not be received.

\subsection{Modes of Responsibility}

In criminal law, responsibility is imposed on an individual because, in some way, he or she has contributed to the commission of a crime. In both domestic and international penal systems, different rules on participation occur. Participation could be direct or indirect, and may take place prior to, during, or after the commission of the crime. In international criminal law, different modes of participation have been expressly stipulated in numerous instruments since the Charter of the Nuremberg Tribunal.

Article $28 \mathrm{~N}$ spells out the different modes of participation as follow:

Modes of Responsibility

An offence is committed by any person who, in relation to any of the crimes or offences provided for in this Statute:

i. Incites, instigates, organizes, directs, facilitates, finances, counsels or participates as a principal, co-principal, agent or accomplice in any of the offences set forth in the present Statute;

ii. Aids or abets the commission of any of the offences set forth in the present Statute; 
iii. Is an accessory before or after the fact or in any other manner participates in a collaboration or conspiracy to commit any of the offences set forth in the present Statute;

iv. Attempts to commit any of the offences set forth in the present Statute.

Very little is added to these modes of participation as they are well-recognised by both numerous international instruments and customary international law. However, the list of the modes of participation enjoys some considerable expansion to include even those who direct or finance any of the crimes over which the Court has jurisdiction. In addition to this, participation is not limited to direct perpetrators who are principal offenders or joint cooffenders. Accessorial participation is clearly spelt out in the relevant subparagraphs, which, in effect and essence broaden the scope of liability that would ensue from participation in any of the crimes over which the Court has jurisdiction.

\subsection{Imposition of Criminal Responsibility}

The Draft Protocol of the Court details specific provisions regarding the imposition of criminal responsibility for both individuals and corporations. The rules on the imposition of criminal responsibility for individuals are stipulated in Article 46B of the Draft Protocol as follow:

Article 46B: Individual Criminal Responsibility

1. A person who commits an offence under this Statute shall be held individually responsible for the crime.

2. Without prejudice to the immunities provided for under international law, the official position of any accused person, whether as Head of State or Government, Minister or as a responsible government official, shall not relieve such person of criminal responsibility nor mitigate punishment. 3. The fact that any of the acts referred to in article $28 \mathrm{~A}$ of the present Statute was committed by a subordinate does not relieve his or her superior of criminal responsibility if he or she knew or had reason to know that the subordinate was about to commit such acts or had done so and the superior failed to take the necessary and reasonable measures to prevent such acts or to punish the perpetrators thereof.

4. The fact that an accused person acted pursuant to the order of a Government or of a superior shall not relieve him or her of criminal responsibility, but may be considered in mitigation of punishment if the Court determines that justice so requires. 
Article 46C: Corporate Criminal Liability

1. For the purpose of this Statute, the Court shall have jurisdiction over legal persons, with the exception of States.

2. Corporate intention to commit an offence may be established by proof that it was the policy of the corporation to do the act which constituted the offence.

3. A policy may be attributed to a corporation where it provides the most reasonable explanation of the conduct of that corporation.

4. Corporate knowledge of the commission of an offence may be established by proof that the relevant knowledge was possessed within the corporation and that the culture of the corporation caused or encouraged the commission of the offence.

5. Knowledge may be possessed within a corporation even though the relevant information is divided between corporate personnel.

6. The criminal responsibility of legal persons shall not exclude the criminal responsibility of natural persons who are perpetrators or accomplices in the same crimes.

7. For the purpose of this section:

"Corporate culture" means an attitude, policy, rule, course of conduct or practice existing within the body corporate generally or within the area of the body corporate in which the relevant activities take place.

\section{$6 \quad$ Assessing the Basel and Bamako Conventions}

These two instruments have been in force for over twenty years. On the other hand, the merged African Court is still prospective. Its assessment therefore can only be a question of foresight. However, it has been over two decades since both these Conventions went into force, and the time is ripe to assess their effectiveness in bringing this illegal activity to an end.

\subsection{The Basel and Bamako Conventions in Comparison}

As discussed above, two principal instruments regulate cross-border transportation of hazardous wastes. The Basel Convention is a global instrument. Specific and limited to Africa is the Bamako Convention. The history of the Bamako Convention is linked to the Basel Convention. As such, there are areas wherein the Basel and Bamako Conventions bear resemblance, some of which are worthy of note. 


\subsubsection{Areas of Convergence}

Both Conventions mention and cover areas related to waste management, ${ }^{41}$ the sovereign rights to ban the importation or transportation of hazardous wastes into their territories, ${ }^{42}$ provision of information on hazardous wastes, ${ }^{43}$ and the regulation of transboundary shipment of wastes. ${ }^{44}$ In addition to these areas, the two instruments do have similar provisions that cover amendments to the Conventions and their Protocols, ${ }^{45}$ adoption of, and amendments to annexes, ${ }^{46}$ dispute resolution and settlement, ${ }^{47}$ and reservations and declarations. ${ }^{48}$ Only with a few exceptions, the definition of terms is identical in both Conventions. ${ }^{49}$ Remarkably conspicuous is the failure to address issues that arise as a result of operational pollutions from ships as this is extensively dealt with in an existing international maritime treaty. ${ }^{50}$

41 The Basel and Bamako Conventions do agree that measures should be taken to reduce the quantity of wastes being generated among countries in the world as the most effective mechanism for environmental protection: See Preamble to the Basel Convention, paras 2 and 3; Preamble to the Bamako Convention, paras 1 and 2. In addition to this, the two Conventions do place responsibility for waste disposal and the associated consequences on the generator of the waste: see Basel Convention, Article 5; Bamako Convention, Article 4 .

42 The two instruments do recognize the sovereign rights of states to ban the importation or transportation of hazardous wastes into or through their territorial space. See Basel Convention, Article 6; Bamako Convention, Article 6.

43 Both Conventions provide that within six months of becoming a party to either Convention, member states should inform their respective secretariats of wastes other than those listed on Annex I that are defined or considered hazardous wastes under its national legislation and any requirements applicable to the transboundary movement of such wastes. See Basel Convention, Article 3; Bamako Convention, Article 3.

44 The two Conventions do make provisions for the regulation of transboundary movement of hazardous wastes among member states. They both require that any transboundary movement of hazardous waste shall be covered by insurance, bond or other guarantee as may be required by the state of import or transit which is a party to the Convention. See the Basel Convention, Article 6, 6(11); the Bamako Convention, Article 6, 6(10).

45 Basel Convention, Article 17; the Bamako Convention, Article 17.

46 Basel Convention, Article 18; the Bamako Convention, Article 18.

47 Basel Convention, Article 20; the Bamako Convention, Article 20.

48 Basel Convention, Article 26; the Bamako Convention, Article 26.

49 Basel Convention, Article 2; the Bamako Convention, Article 1.

5o Basel Convention, Article 1(4); the Bamako Convention, Article 2(3). The applicable international instrument on operational pollution from ships is the MARPOL1973/78, 12 ILM 1319 (1973). 


\subsubsection{Areas of Divergence}

Although there are a few areas where the two Conventions converge, a closer look at these instruments reveals numerous areas of divergence: the definition of the scope of wastes covered by the two Conventions, the total ban on the importation of wastes, the Prior Informed Consent (PIC) regime, environmental standards, liability, illegal traffic, information and the establishment of a Secretariat.

\subsection{Assessing the Bamako Convention}

Since its adoption, the Bamako Convention has been the instrumentum laboris for the African Continent in regulating and monitoring cross-border transportation of hazardous wastes. As a legal mechanism, the Convention has achieved some success.

\subsubsection{Successes}

The Bamako Convention has some landmark accomplishments. One of these is broadening the definitive scope of what constitute hazardous wastes. The Bamako Convention addresses a wider spectrum of hazardous wastes. No international instrument, prior to, or after it, does this. The concept of hazardous wastes is broadly defined. It contains a list of hazardous wastes in Annex I. in addition, it categorises other wastes that possess the characteristics contained in Annex II, or are considered as hazardous under domestic legislation of the state of import or transit fall within the definition of hazardous wastes under the Convention. The Convention regulates the transboundary movement of not only hazardous wastes: 'radioactive' wastes are included.

Another accomplishment of the Bamako Convention is the complete prohibition of the importation of hazardous and radioactive wastes into Africa irrespective of the circumstances, recycling included. Recycling was the argument used by many developed countries to take advantage of the economic poverty in Africa to lure them with financial incentives. One of the objectives of the Bamako Convention is to put an end to this, at least, in theory.

The Bamako Convention bans the import of hazardous wastes into Africa. However, it permits the transboundary movement of hazardous wastes generated within Africa. This transboundary movement, however, is subject to some stringent regulatory controls. The Convention insists on specific shipment notification notwithstanding the frequency or characteristic similarity of the wastes being carried. This ensures proper monitoring of individual wastes shipment. It also safeguards against the gullibility to abuse that the general notification under the Basel Convention is susceptible to. In addition, specific 
provisions on strict, unlimited, joint and several liability of persons and the punitive measures against persons involved in illegal traffic and generation of wastes act as a deterrent against engaging in such 'act of criminality'.

\subsubsection{The Bamako Convention: Its Limitations}

Despite the existence of international instruments regulating the ban on transboundary movement of hazardous wastes into Africa, a number of countries have been clandestinely involved in this illegal activity. Many reasons have been postulated to account for the flagrant violation of this. Most of these reasons are based on economics: the desperate and urgent need to alleviate the economic hardships faced by these African countries. Lured by the potential of the huge financial gain, some of these transactions have triggered enormous profits that exceed the GDPs of some African countries. Some African countries that have accepted the transboundary movement of hazardous wastes attribute it to the prevalent economic crisis in their states which include severe balance of payments deficits, civil wars created by, among other factors, weak income earning power, external loan payment defaults. Even though the regulations are in place, the incidents that have occurred in many African countries have raised serious concerns over the effectiveness of these instruments regulating the ban on transboundary movement of hazardous wastes. The cases of Benin, Nigeria, Guinea-Bissau, Côte d'Ivoire, Somalia, Zimbabwe are illustrative of the African states that have engaged in transactions that flagrantly violate both the spirit and letter of the OAU Bamako Convention.

Despite the milestones discussed above, there are some shortcomings of the Bamako Convention that explain why transboundary movement of hazardous wastes across African states has not stopped.

\section{Lack of Political Will for the Implementation of the Convention}

The adoption of the Bamako Convention was a clear demonstration that African states were completely dissatisfied with the protection accorded by the Basel Convention. However, the ratification of the Convention has suffered from a remarkable slowness, which is a major indicator of the absence of universal support and acceptance amongst African states themselves. As a result, the Bamako Convention only came into force in 1998. As of February 2010, it had been ratified by only 23 African countries.

Regarding the development and implementation of regulations and priority funding, the response from most African states has been one of suspicion and apathy. 


\section{The Economic Realities of African States}

In addition to the lack of a political will for the implementation discussed above, transboundary movement of hazardous wastes across Africa remains undeterred because of the daunting economic realities faced by African states. The implementation of environmental law (both international and domestic) in Africa is partly and largely influenced by economic, technological and political factors. For a continent where poverty and misery are never on a permanent vacation, and many are entangled in financial and economic difficulties, the importation of hazardous wastes is rewarded by the promises of huge financial gains which serve as a source of foreign revenue for these poor states. Statesmen have disclosed on public podium how such illegal trade would boost their national economies, making them completely oblivious to poisonous consequences and unpalatable ramifications of such illegal transactions.

\section{Absence of Waste Management Technologies}

As a consequence of its chronic poverty, the relevant technology for the treatment of hazardous wastes is almost absent. The Bamako Convention prescribes strict measures regulating the transboundary movement of hazardous wastes among states party. Unfortunately, the Convention does not contain any specific provisions on the development of the requisite waste management technologies that would, at least, in theory, minimise such activity within the African continent.

\section{Inadequate International Cooperation}

The Bamako Convention makes no provision for the cooperation of its Secretariat with the Basel Secretariat. It is self-evident that collaborative cooperation with the Basel Convention as well as other regional Secretariats and intergovernmental, non-governmental organisations is needed for the successful implementation of the aspirations of the Bamako Convention.

\section{$7 \quad$ Addressing the Inadequacies of International Instruments}

The incidents in Côte d'Ivoire, Benin, Nigeria, Guinea-Bissau, Sao Tome and Principe and Somalia, are all indicative of a simple and undeniable truth: international instruments are inadequate in dealing with the issue of transboundary movement of hazardous wastes. Inasmuch as transboundary movement of hazardous wastes is an important angle to protect environmental degradation, the complicity of nationals on whose territories the dumping took place, and the slowness in the response reveal that a comprehensive approach is needed 
to prevent transboundary movement of hazardous wastes in particular, and other activities harmful to the environment in general. In addition to the international regulatory framework, African states should develop strong legal systems with sound laws and policies that protect the environment from every kind of degradation. In addition, education of the nationals would be priceless in achieving this goal. Lastly, a strong civil society will be invaluable in ensuring that international law and standards as well as national statutes are implemented by all relevant stakeholders.

\subsection{Development, Enactment and Enforcement of Sound Laws and Policies}

Beyond signing, acceding to, or ratifying an international agreement, states are expected to take steps, especially legislative, to ensure that the substantive content of these agreements are incorporated into national laws. The Basel Convention requires state parties to 'take appropriate legal, administrative and other measures to implement and enforce the provisions' contained therein. ${ }^{51}$ Legislative and administrative measures imply the enactment of laws, adoption of policies, standards and guidelines that deal with environmental protection.

Many poor African states are overwhelmed by, and caught in the uneasy struggle between economic development and environmental management. Environmental degradation becomes the ultimate and heavy price that these states must pay as they pursue economic growth. The two may appear to be irreconcilable, especially with the untenable view that upon the achievement of economic growth, environmental issues will gradually and progressively be attended to. The experience of developed industrialised nations not only debunks this thinking, it exposes the flawed and irrational approach that such African states have taken towards economic development. Economic growth and environmental protection are complementary of each other if and when pursued wisely and rationally. For this to happen, sound laws and policies are needed. ${ }^{52}$

$5^{1} \quad$ Basel Convention, Article 4(4).

$5^{2}$ The incidents that occurred in Nigeria (fn 10 and 14), Sao Tome (fn 11), Benin (fn 9), Somalia ( $\mathrm{fn} 12$ ) and Côte d'Ivoire ( $\mathrm{fn}$ 1), were partly attributable to the absence of sound laws and policies on environmental protection. Following these incidents, some of these countries enacted tougher laws. For example, Nigeria instituted the death penalty on anyone involved in waste trading. See <http://wwwl.american.edu/ted/nigeria.htm> accessed on 10 January 2015 . 
One reason that accounts for the continued practice of transboundary movement of hazardous wastes from developed industrialised countries to Africa is the absence of effective laws and policies to protect the environment. Even when these laws are in force, another big challenge is enforcement. The perpetration of these illegal activities in African countries has been done with the complicity of top political and public figures: cases in point include the Côte d'Ivoire toxic waste incident, ${ }^{53}$ the Guinea-Bissau incident, ${ }^{54}$ and the Benin case. ${ }^{55}$ The legal system of most countries is weak, porous and unreliable for any effective legal action aimed at protecting the environment. The absence of strong and sound laws and policies make Africa extremely vulnerable to such illicit and criminal practices, and highlights the urgent need for the enactment of laws that will protect the environment. Beyond the enactment of, or amendments to, these laws, a strong culture of rule of law is needed to ensure that everyone is subjected to the laws of the state.

Urban cities in most African countries are struggling with the challenges of economic growth and increased human activities with a heavy toll on the environment. The belief is that for economic growth to occur, the environment must pay the price. Urban cities are the hubs of poisonous air, lack of open space, uncollected garbage, accumulation and poor disposal of domestically generated hazardous wastes, water pollution due to disposal of wastes, congestion, noise, traffic jam, and dying and polluted water bodies, do amalgamate to make life in most of Africa's metros unbearable and unhealthy.

53 Following the toxic waste incident in Côte d'Ivoire, many top government figuresquit the government: see 'Ivorian Cabinet quits over waste: Ivory Coast Prime Minister Charles Konan Banny has dissolved his cabinet over a toxic waste scandal in Abidjan' (ввС 7 September 2006, 07 :32 (GMT)) <http://news.bbc.co.uk./2/hi/africa/5321272.stm> accessed on 9 January 2015; 'COTE D'IVOIRE: Cabinet resigns over toxic fumes scandal' (IRIN Africa) < http://www.irinnews.org/report/60834/cote-d-lvoire-cabinet-resigns-over -toxic-fumes-scandal $>$ accessed on 10 January 2015.

54 See for example, in 1988, when the Government of Guinea-Bissau agreed to accept over 15 million tons of toxic wastes for US $\$ 600$ million: an amount four times its GNP. The Minister of Trade and Tourism retorted, 'We need money': 'Africa: The Industrial World's Dumping Ground?', African Business (July 1988) 10-11.

55 It is alleged that the President of Benin, President Kerekou, was actively involved in negotiating the deals that would lead to the dumping of hazardous wastes in Benin. In the deal with the Soviet Union, a London-based biweekly bulletin alleged that the President was aware of the secretive dumping deal. In the 1988 deal with France, Commandant of the Ganvie (Benin's merchant-marine vessel), Seraphin Noukpo, acknowledged that he transported the shipment of nuclear wastes from Le Havre in France. See Benin (fn g). 
With such trends and realities, the undeniable truth is that these cities repel rather than attract investment. The prohibition of transboundary movement of hazardous wastes is simply one dimension of the problem that will not and never be a magic bullet to Africa's degrading and depleting environment. As city dwellers are exposed to these kinds of pollution, there is an urgent call that is made to law makers to rethink and revise the relevant laws and policies in place, and build strong enforcement mechanisms in the hope that environmental protection is a key aspect of urban development and economic growth.

\subsection{Transparency and Accountability on Environmental Laws and Policies and Projects}

Inasmuch as sound laws and policies are needed to bolster the effectiveness of the relevant international instruments, governments and other stakeholders should be transparent and open to the public when they engage in deals that involve the transboundary movement of hazardous wastes. ${ }^{56}$ Information ought to be shared on the source of the hazardous wastes, its ultimate destination, the toxicity of the wastes, the plans in place to destroy, recycle or dispose of the wastes, and more importantly, what dangers it poses to the health of the people in the environs as well as the environment.

The call for transparency is sparked by the numerous surreptitious deals that were brokered between the shipping enterprises and the governments of the countries in question. Had civil society been contacted or consulted, plenty of questions would have been asked, and probably answered, or the dangers exposed to the anticipated victims. Effective implementation of the prohibition of hazardous wastes therefore requires parties to such deals to be transparent with every stakeholder, so that basic questions that have to be raised are answered.

\subsection{Environmental Education for Humanity and the Environment}

Education and awareness are needed for the benefit of both mankind and environment. Sound and wise management of the environment, including the complete and effective prohibition of transboundary movement of hazardous wastes, requires environmental education. ${ }^{57}$ Individuals in their different

56 In most of these cases, the government operated in a clandestine way. The contents of the deal were never disclosed to the public. Transparency as a cornerstone of good governance requires openness in the conduct of public affairs.

57 Environmental education in this context refers to the teaching (whether formal or informal) of individuals and communities on how to transition into societies that are knowledgeable of their environment, the problems it faces, and developing solutions to these 
communities must be enlightened to understand that a safe, healthy and wellprotected environment is very vital for the safety and well-being of the people in that environment.

Rural and urban dwellers alike need to be educated, both formally and informally, on the urgent necessity to respect, protect and promote the environment. Through community outreach programmes via the media and other public outlets, everyone in the community should be made to understand that there is a huge and direct relationship between mankind and the environment it occupies. Mankind's activities affect the environment, and vice-versa. As such, in making decisions that affect the environment, individuals in communities should be made to understand that poor wastes disposal, water and air pollution, and other harmful activities would definitely trigger consequences that are harmful to the same perpetrators. Poor wastes disposal, water and air pollution affect our quality of life, breed mosquitoes, make water undrinkable, generate unbearable stench, give an unsightly appearance to the vicinity in question, and more importantly, compromise our right to a safe, clean and healthy environment.

Communities should be informed of the dangers of these hazardous wastes, be educated on what they can do if they notice any suspicious activity in their communities. Poor environmental management affects the lives and livelihood of the people. Rather than conceal such illegal and criminal activities, they should alert the authorities whenever they suspect, witness or are victims of any activity that they think is harmful to the environment.

Through education, communities become aware of the importance to protect the environment, the need to desist from engaging in activities that are harmful to the environment, the relationship they have with the environment, and lastly, what they should do in the event that activities harmful to the environment are carried out.

problems with the motivation to surmount them. It encompasses engaging with citizens of all walks of life to think critically, ethically, rationally, and creatively when evaluating issues related to the environment, to make sound judgments on these issues, develop skills and a commitment to act both independently and collectively to sustain and enhance the environment and to enhance their appreciation of the environment, resulting in positive environmental behavioural change. See S Bamberg and G Moeser, 'Twenty Years after Hines, Hungerford, and Tomera: A New Meta-Analysis of Psycho-Social Determinants of Pro-Environmental Behaviour' (2007) 1 Journal of Environmental Psychology 14. 


\subsection{Developing and Supporting a Virile Civil Society}

In order to understand the role that civil society can play in curbing transboundary movement of hazardous wastes in particular and environmental management and sustainability in general, it is important to delineate the concept of civil society. Civil society has been depicted as that sphere of social life that is public but excludes governmental activities. ${ }^{58}$ It is some social interaction that exists between the household on one hand, and the state on the other hand, that is characterised by community cooperation, networks of public communication and structures of voluntary association. ${ }^{59}$ It is a phrase of common and general usage employed to mean the classification of persons, institutions and organisations all having the goal of advancing or expressing a common purpose. ${ }^{60}$ This is done through ideas, actions, and demands on governments. ${ }^{61}$ Membership is diverse: it comprises individuals, religious entities, academic institutions, and non-governmental, charitable and nonprofit-making organisations. ${ }^{62}$ With regard to environmental issues, nongovernmental organisations standout given the diverse roles and activities they can, and do, carry out. ${ }^{63}$

Across the globe, and in Africa in particular, numerous NGOs are involved in issues related to the environment. ${ }^{64}$ These NGOs operate at different levels

58 Errol Meidinger, 'Law Making by Global Civil Society: The Forest Certification Prototype' (Baldy Center for Law and Social Policy, State University of New York at Buffalo, Buffalo, NY, 2001) < http://web2.law.buffalo.edu/faculty/meidinger/scholarship/GCSEL.pdf > accessed on 10 January 2015 .

59 See generally Michael Bratton, Civil Society and Political Transition in Africa (Institute for Development Research Massachusetts 1994).

6o Barbara Gemmill and Abimbola Bamidele-Izu, 'The Role of NGOs and Civil Society in Global Environmental Governance' in Daniel C Esty and Maria H Ivanova (eds) Global Environmental Governance: Options \& Opportunities (Yale School of Forestry and Environmental Studies 2002) 1, 3 .

61 See generally Jean L Cohen and Andrew Arato, Civil Society and Political Theory (m Iт Press 1992).

62 Gemmill et al (n 6o) 3 .

63 Charnovitz defines NGOs as '[g]roups of individuals organized for the myriad of reasons that engage human imagination and aspiration. They can be set up to advocate a particular cause, such as human rights, or to carry out programs on the ground, such as disaster relief. They can have memberships ranging from local to global.' See Steve Charnovitz, 'Two Centuries of Participation: NGOs and International Governance' (1997) 2 Michigan Journal of International Law 183, 186.

64 Examples of these NG Os abound. For example, 350.org, A Rocha, Anti-nuclear movement, Antinea Foundation, Arab Forum for Environment and Development, Biofuelwatch, Biosphere Expeditions, Bioversity International, Dancing Star Foundation, Deep Green 
(local, national, regional, and international) and their missions vary from environmental protection, poverty alleviation, animal welfare, sustainable development to other issues.

Agenda 21, perceived as the blueprint on comprehensive sustainable development, adopted at the Rio Earth Summit in 1992, acknowledges the diversity of civil society and its value to official intergovernmental processes on the environment. Even though the document makes no express use of the phrase civil society, it does recognise the different members of civil society as a major constituency. The Commission on Sustainable Development, mandated for implementing Agenda 21, has classified civil society to include women, children and youth, farmers, business and industry, workers and trade unions, NGOS, the scientific and technological community, and indigenous peoples and communities.

The question is how can civil society contribute to the effective and absolute prohibition of transboundary movement of hazardous wastes? Civil society can do this through many ways. First, through monitoring and assessment. ${ }^{65}$ Civil society can help strengthen international agreements on transboundary movement of hazardous wastes by monitoring negotiations on the issue as well as governmental compliance. ${ }^{66}$ Secondly, civil society can act as a representative of the voiceless by helping vocalise the interests of persons who are not well represented in policymaking. In addition, civil society can mobilise public opinion which is done by influencing the public through campaigns and outreach. Furthermore, it can offer expert advice and analysis to government and other stakeholders. ${ }^{67}$ Civil society facilitates negotiations by giving the government, opposition, and other stakeholders access to competing ideas

Resistance, Earth Charter Initiative, Earthwatch, Environmental Defense Fund, Fauna and Flora International, Forest Stewardship Council, Forests and the European Union Resource Network (FERN), Friends of Nature, Friends of the Earth, Partners in Population and Development, Plant A Tree Today Foundation (РATT), PRво Conservation Science, Programme for the Endorsement of Forest Certification, Project AWARE, Rainforest Alliance, Rainforest Trust, Sandwatch, Sano Sansar Initiative, Seeds of Survival of UsC Canada, Society for the Environment (SocEnv), Taiga Rescue Network (TRN), The Climate Project, The Mountain Institute, The Nature Conservancy, The Resource Foundation, Wetlands International, Wildlife Conservation Society, Wolf Preservation Foundation (WPF), World Business Council for Sustainable Development, World Conservation Union (WCU), World Land Trust (WLT), World Resources Institute (WRI), World Union for Protection of Life (WUPL), World Wide Fund for Nature (WWF).

65 Gimmell et al (n 6o) 7 .

66 Ibid.

67 Ibid. 
emanating from external normal bureaucratic channels. ${ }^{68}$ In providing services, civil society deliver technical expertise on specific topics as and when needed by government officials. They also participate directly in operational activities that affect the environment. ${ }^{69}$ Civil society also creates intellectual competition to governments given the huge and invaluable analytical and technical skills and capacity they have, especially as their response to issues and crises is quicker and more effective. ${ }^{70}$ Finally, through the legitimization of global-scale decision making mechanisms, civil society could contribute significantly to ensuring that hazardous wastes are not exported into, or moved within African countries. ${ }^{71}$ The performance of this role requires a broadening of the base of information required for decision-making, the improvement of the quality, authoritativeness and legitimacy of policy choices of international organisations. ${ }^{72}$

Governmental and intergovernmental organisations are marred by rapid decision-making processes, hampered by the lack of sufficient analytical capacity and slowed by numerous bureaucratic constraints and obligations. Civil society, on the other hand, can quickly and rapidly develop and focus on a dynamic research agenda, and then move to other issues.

For civil society to play this role, it must be given the support it needs. Such support varies from creating the legal climate such as freedom of association and participation, ensuring that members are not victimised for forming, holding and expressing opinions that are contrary to the government's, given the required resources to do the job, ensuring that details of business deals and agreements are made open and subjected to public scrutiny, assistance in the form of network, providing sufficient room for agreement and disagreement between governmental figures, stakeholders, and civil society, and also effective use of civil society for consultation with the public. ${ }^{73}$ When these are done, and incorporated into public policy decision-making process, civil society in general, and NGOs in particular are not only acknowledged, but elevated to important stakeholders in environmental governance, and depicted as an indispensable driving force behind greater environmental protection through

\begin{tabular}{ll}
\hline 68 & Ibid. \\
69 & Ibid. \\
70 & Ibid. \\
71 & Ibid. \\
72 & Ibid. \\
73 & Ibid.
\end{tabular}


the mobilisation of public support for the laws in force and disclosure of activities that are harmful to the environment. ${ }^{74}$

African states should therefore, as an additional step in ensuring the complete eradication of transboundary movement of hazardous wastes in Africa, enable the constructive participation of civil society. Such participation should permit civil society to play leading and influential roles in the domains of information collection and dissemination, policy development consultation, the implementation of policies, assessment and monitoring and finally, advocacy for environmental justice.

\section{Conclusion}

Given the weak regulatory environmental regime, the docility of civil society, economic constraints and considerations and inadequate and ineffective institutional mechanisms plus laws saturated with loopholes, Africa will always remain a viable and affordable option when considering a destination for dumping of hazardous wastes. The costs of disposal are very low, and the disposal process entails nothing more than finding a site (whether suitable or unsuitable). These toxic substances can be interred without being processed with little or no adherence to international and local environmental regulatory standards. Low public awareness of the risks involved, and the willingness of some African leaders and business individuals to ignore these risks in exchange for financial gains, have further facilitated the entire process.

African states are caught in an ugly dilemma: the desperate need to get out of poverty and the circumvention of the potential far-reaching harm which toxic waste can ultimately have on the environment and its people. The answer to this question depends on whether Africans should settle for short-term benefits as opposed to the inevitable, long-term more harmful and expensive costs? African countries that permit the importation of hazardous wastes from developed industrialised countries must note that in reality, the exporters gain the most from such deals. By using Africa as a dumping site, developed industrialised countries eschew the high costs of incinerating and recycling their wastes according to established rules and guidelines. In effect, Africa picks up the cost of cleaning the damage caused by the wastes, which in effect nullifies the entire attempt to generate revenue to alleviate poverty. In addition, such reckless and irresponsible decisions put their own people who have to be protected into jeopardy. 
The criminalisation of illegal trafficking of hazardous wastes is significant progress in achieving the aspirations of the Basel and Bamako Conventions. The numerous cases that have occurred on African soil reveal that corporate entities as well as individuals are complicit in the planning, preparation and execution of this crime. Like other crimes that are of common occurrence on the African soil, the role of corporations cannot be overlooked. The inclusion of principles on the imposition of responsibility on corporations that are complicit in the crimes over which the Court has jurisdiction is a great development as it not only sends clear signals to potential suspects, but also brings them under its jurisdiction. These international instruments, as well as the criminalisation of illegal trafficking in hazardous wastes, can only be very effective if, and only when, African states muster the courage and political will to combat it in every form, without respect to their economic realities, for the crime itself poses a grave danger to human lives, health and environment of those who are affected. 